\title{
Effects of Water Management Strategies and Nitrogen Fertilizer on Rice Yield Cultivated on Histosols
}

\author{
Naba R Amgain ${ }^{1 *}$, Abul Rabbany ${ }^{2}$, Salvador Galindo ${ }^{3}$ and Jehangir H Bhadha ${ }^{4}$ \\ ${ }^{1}$ Postdoctoral Associate, Everglades Research and Education Center, University of Florida, USA \\ ${ }^{2}$ Chemist III, Everglades Research and Education Center, University of Florida, USA \\ ${ }^{3}$ Agricultural Assistant I, Everglades Research and Education Center, University of Florida, USA \\ ${ }^{4}$ Assistant Professor, Soil and Water Sciences Department, University of Florida, USA
}

\begin{abstract}
Rice cultivation in a continuous flooding system is common practice. However, due to the scarcity of continuous irrigation alternate water management strategies are being explored for rice cultivation. The objective of this study was to evaluate the effects of alternative water management strategies and nitrogen fertilizer on rice yield grown on highly organic (Histosol) soils. The treatments included: Continuous flooding (CF); continuous flooding + nitrogen (CF + N); alternate wetting and drying (AWD); alternate wetting and drying + nitrogen (AWD + N); single mid-season drawdown (SMD); and single mid-season drawdown + nitrogen $(S M D+N)$. Results revealed that treatment had no significant effect on yield, total phosphorus (TP), total potassium (TK), and total Kjeldahl nitrogen (TKN) concentration in leaf tissue, soil, and water. In addition, treatment did not affect soil and water $\mathrm{pH}$. However, soil $\mathrm{pH}$ was decreased after cultivation whereas Mehlich-3 P (M3P) and Mehlich-3 K (M3K) concentration had increased after cultivation irrespective of treatment. These results indicate that AWD and SMD could be a good alternative water management strategy for rice cultivation on Histosols where continuous irrigation may be challenging.
\end{abstract}

\section{Keywords}

Alternate wetting and drying, Continuous flooding, Histosols, Rice, Single mid-season drawdown

\section{Abbreviations}

AWD: Alternate Wetting and Drying; CF: Continuous Flooding; SMD: Single Mid-season Drying; N- Nitrogen; TP: Total Phosphorus, TK: Total Potassium; TKN: Total Kjeldahl Nitrogen

\section{Introduction}

Rice is traditionally grown under continuous flooding (CF) conditions. However, water scarcity in recent years has increased the restriction of agriculture production, and there is need to developed alternative systems that required less water [1]. It is expected that by 2025 , about $20 \%$ of irrigated rice areas will experience physical water scarcity [2]. Several studies reported resource conservation technologies can be used to grow rice under less water [3-6]. Although CF has the benefit of better weed controls and optimum plant stand, it requires more water, reported to degrade soil due to formation of plow pan, and soil particle disintegration, higher emission of methane, elevate global warming potential, increase grain accumulation of mercury, and arsenic [4]. Therefore, an alternative resource-conservation system that has minimal effect on ecosystem health is required. Alternative wetting and drying (AWD) [4,7-9] and single mid-season drying (SMD) $[10,11]$ are commonly practiced alternative water-saving practices adopted in the rice production system. Under AWD, fields are subjected to alternate wet and dry rather than continuous flooding. The field is allowed to dry for 1 or 2 days and then re-flooded. Mid-season drainage involves the removal of surface water from the rice field for about 7-10 days towards mid to late tillering. The success of AWD and SMD depends on climatic conditions, rainfall, and soil types [12].

Environmental conditions and agronomic management practices affect the yield of rice. Nitrogen $(\mathrm{N})$ is considered the

*Corresponding author: Naba R Amgain, Postdoctoral Associate, Everglades Research and Education Center University of Florida, Florida, USA

Accepted: October 19, 2021

Published online: October 21, 2021

Citation: Amgain NR, Rabbany A, Galindo S, et al. (2021) Effects of Water Management Strategies and Nitrogen Fertilizer on Rice Yield Cultivated on Histosols. J Rice Res Dev 4(1):331-338 
nutrient that most often limits crop production [13]. In rice cultivation system, the concern about fertilizer management has increased due to water contamination and soil degradation from nutrients that are applied. The lower recovery rate of $\mathrm{N}$ may be related to gaseous loss of $\mathrm{N}$, immobilization of $\mathrm{N}$, and leaching loss of $N[14,15]$. However, the effect of irrigation on $\mathrm{N}$ dynamics in rice has not been studied extensively. Atwill, et al. [16] reported AWD irrigation did not reduce $\mathrm{N}$ use efficiency, plant height, or yield compared to the CF system in Louisiana and Mississippi. Some case studies have demonstrated that the $\mathrm{N}$ requirement of microorganisms that decompose organic matter in flooded soils is lower than for decomposers in aerated soils which results in lower net $\mathrm{N}$ immobilization in flooded soils than in aerobic, well-drained soils [17]. The objective of this study was to evaluate the effect of alternative water management strategies and $\mathrm{N}$ on rice grown on organic soil in the Everglades Agricultural Area (EAA) of South Florida. Conventional rice production in the region does not include any nitrogen $(N)$, phosphorus $(P)$ or potassium (K) fertilization [18]. In the EAA, different water management scenarios need to be studied to select the most appropriate flooding system for rice fields. Optimizing pumping costs and water conservation are also important concerns in increasing the production efficiency [19].

\section{Materials and Methods}

To understand the effect of alternative water management strategies on rice yields an experiment was conducted at the University of Florida, Everglade Research and Education Center (EREC). Diamond variety of rice was seeded at 101 $\mathrm{kg} \mathrm{ha}^{-1}$ in 265-liter pots containing Histosol available in EAA areas and flooding was initiated 3 weeks after planting (2-3 emerging leaf stage). As shown in Table 1, the treatments included i) Continuous flooding (CF); ii) Continuous flooding + nitrogen $(\mathrm{CF}+\mathrm{N})$; iii) Alternate wetting and drying (AWD); iv) Alternate wetting and drying + nitrogen $(A W D+N)$; v) Single mid-season drawdown (SMD); vi) Single mid-season drawdown + nitrogen $(S M D+N)$. Under continuous flood (CF) condition $15 \mathrm{~cm}$ flood-depth was maintained throughout the growing season. Alternate wet and dry (AWD) pots were maintained at $15 \mathrm{~cm}$ flood-depth for 2 weeks, followed by a complete drawdown for 1 week. Three such cycles of 2-week flood followed by 1-week drawdown were managed throughout the growing season. Single mid-season drawdown (SMD) pots continuously received water at $15 \mathrm{~cm}$ flood-depth for 5 weeks, followed by a complete drawdown for 1 week in the mid-tillering stage after which water was raised back to $15 \mathrm{~cm}$ throughout the growing season. The treatments were arranged in a randomized completed block design with four replications of each treatment. Steady flooded conditions for rice growth were maintained using canal water available from the EAA. The parameters evaluated include rice yield, plant tissue analyses, and extractable nutrient in soil and water. Canal water was used to water the treatments.

Soil samples were collected before planting rice (pre) and after harvesting rice (post). All samples were oven-dried and sieved through a 2-mm screen. Soil samples were analyzed for $\mathrm{pH}$, total phosphorus (TP), total potassium (TK), Mehlich-3 P (M3P), Mehlich-3 K (M3K), and total Kjeldahl nitrogen (TKN). $\mathrm{pH}$ was measured using $1.5 \mathrm{~g}$ of dried soil mixed with $7.5 \mathrm{~mL}$ of deionized water (1:2 soil: Solution) and analyzed using an Accumet AB250 pH meter. This meter was calibrated before testing with 4, 7, and $10 \mathrm{pH}$ standards. Total $\mathrm{P}$ was determined by ashing samples for at least 5 hours (not to exceed 16 hours) at $550{ }^{\circ} \mathrm{C}$ in a muffle furnace followed by extraction with $6 \mathrm{M} \mathrm{HCl}$ and analyzed using an inductively coupled plasma-optical emission spectrometer (5110 ICP-OES, Agilent Technologies Inc., CA) (EPA method 200.7). Available P, and K, were measured using Mehlich-3 extraction. For soil nutrient analyses, $2 \mathrm{~g}$ of soil was weighed and transferred into a $50-\mathrm{mL}$ extraction bottle. $20 \mathrm{~mL}$ of Mehlich-3 extracting solution was dispensed into each extracting bottle with a pipette. Samples were shaken for 5 minutes on a reciprocating shaker and then filtered through a Whatman No. 42 filter paper and acidified using $2 \% \mathrm{HNO}_{3}$. The filtrates were analyzed for nutrients using 5110 ICP-OES, Agilent Technologies Inc., CA. Total Kjeldahl nitrogen (TKN) was analyzed by digestion followed by colorimetric determination (EPA method 351.2). Before testing, the system was calibrated using mixed calibration standard solutions and the calibration blank. This reduced

Table 1: Water management program under continuous flooding (CF), alternate wetting and drying (AWD), and single mid-season drying (SMD)

\begin{tabular}{|l|c|c|c|}
\hline Weeks after rice Planting & Water Sampling & \multicolumn{3}{|c|}{ Water management Strategies } \\
\hline Week 1 & $\sqrt{ }$ & & \\
\hline Week 2 & $\sqrt{ }$ & & \\
\hline Week 3 & $\sqrt{ }$ & & \\
\hline Week 4 & $\sqrt{ }$ & & \\
\hline Week 5 & $\sqrt{ }$ & & \\
\hline Week 6 & $\sqrt{ }$ & & \\
\hline Week 7 & $\sqrt{ }$ & & \\
\hline Week 8 & $\sqrt{ }$ & & \\
\hline Week 9 & $\sqrt{ }$ & & \\
\hline Week 10 & $\sqrt{ }$ & & \\
\hline
\end{tabular}


error by establishing and calibrating the analytical curve. Once the samples were analyzed, the resulting values were used to calculate concentrations of the different elements present.

Water samples were collected weekly once flooding was initiated 3 weeks after planting for a total of 10 weeks. A 50 $\mathrm{mL}$ syringe was used to syphon surface water from the pots into $50 \mathrm{~mL}$ polypropylene vials. Samples were analyzed for $\mathrm{pH}$, total $\mathrm{P}$, total $\mathrm{K}$, and TKN. For $\mathrm{pH}$, approximately $20 \mathrm{~mL}$ of sample was poured into a disposable scintillation bottle for testing. The samples were then tested with an Accumet AB250 pH meter. The meter was calibrated beforehand with 4,7 , and $10 \mathrm{pH}$ standards. Total $\mathrm{P}$ and $\mathrm{K}$ were analyzed using 5110 ICP-OES, Agilent Technologies Inc., CA. The ICP-OES was first calibrated using mixed calibration standard solutions and the calibration blank. This reduced error by establishing and calibrating the analytical curve. If the samples were above the upper limit of quantification, they were diluted to a measurable concentration. Total Kjeldahl nitrogen (TKN) was analyzed by digestion followed by colorimetric determination (EPA method 351.2). In addition to water and soil analyses, treatment effects were also assessed on rice leaf tissues and ultimately rice yields. Yields were estimated on a perpot basis and converted to $\mathrm{kg} \mathrm{ha}^{-1}$. Leaf tissue samples were collected at 47 days after planting and analyzed for TP, TK, and TKN. Total $P$ and TK were analyzed by ashing $0.4 \mathrm{~g}$ dry tissue sample for 5 hours at $550^{\circ} \mathrm{C}$ in a muffle furnace followed by extraction with $6 \mathrm{M} \mathrm{HCl}$ and analyzed using 5110 ICP-OES, Agilent Technologies Inc., CA. The spectrometer was first calibrated with standard solutions and a blank. In total, 48 soil samples, 200 water samples, and 24 plant tissue samples were analyzed as part of this study.

\section{Statistical Analysis}

Data were analyzed through randomized complete block design with four replications using PROC MIXED procedure in
Statistical Analysis of Variance (SAS version 9.4, SAS Institute Inc., Cary, NC, USA). Means were separated using Fisher's protected LSD when the $F$ test was significant at $p<0.05$.

\section{Results and Discussions}

\section{Relative yields}

Irrigation management and the addition of $\mathrm{N}$ had no significant effect on rice yield (Figure 1). No difference in yield due to application of $\mathrm{N}$ may be due to soil rich in $\mathrm{N}$ content.

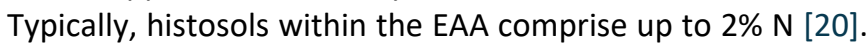
Carrijo, et al. [9] observed a decrease in yield by $5.45 \%$ and water use by $25.7 \%$ under AWD compared to CF. Although AWD decreased yield, it has increased water productivity by $24.2 \%$. Yield losses were more pronounced in soil with $\mathrm{pH}>7$ and $\mathrm{SOC}<1 \%$ [9]. In contrast to our result, Norton, et al. [8] observed a $9.8 \%$ and $9.0 \%$ increase in grain mass in 2013 and 2014 respectively in the AWD plots compared to the CF plots. The increase in grain mass could be associated with an increase in productive tiller. The effect of AWD on tiller production is not clear. Howell, et al. [21] observed an increase in the number of productive tillers under AWD compared to CF but observed a decrease in grain per panicle. However, Yang and Zhang, et al. [22] reported no significant difference in the number of tillers under AWD compared to CF. The increase in productive tiller could have increased the grain mass [22]. Liu, et al. [10] reported mid-season drainage did not affect rice yield. However, the rice yield was significantly affected by soil organic carbon (SOC), total nitrogen (TN), C: $N$ ratio, and $\mathrm{N}$ fertilizer application. Under mid-season drainage, rice yield decreased in soil with low SOC levels, high levels of TN, C:N ratio in a range of $9.0-12.0$, and soil that received $\mathrm{N}$ at $<50 \mathrm{~kg}$ $\mathrm{ha}^{-1}$. Mid-season drainage had increased rice yield in soil with moderate SOC, and low level of TN. The authors reported yield was not affected by field drainage times and organic matter amendment rate. Soil drying due to AWD and SMD could also impact the grain yield production compared to CF.

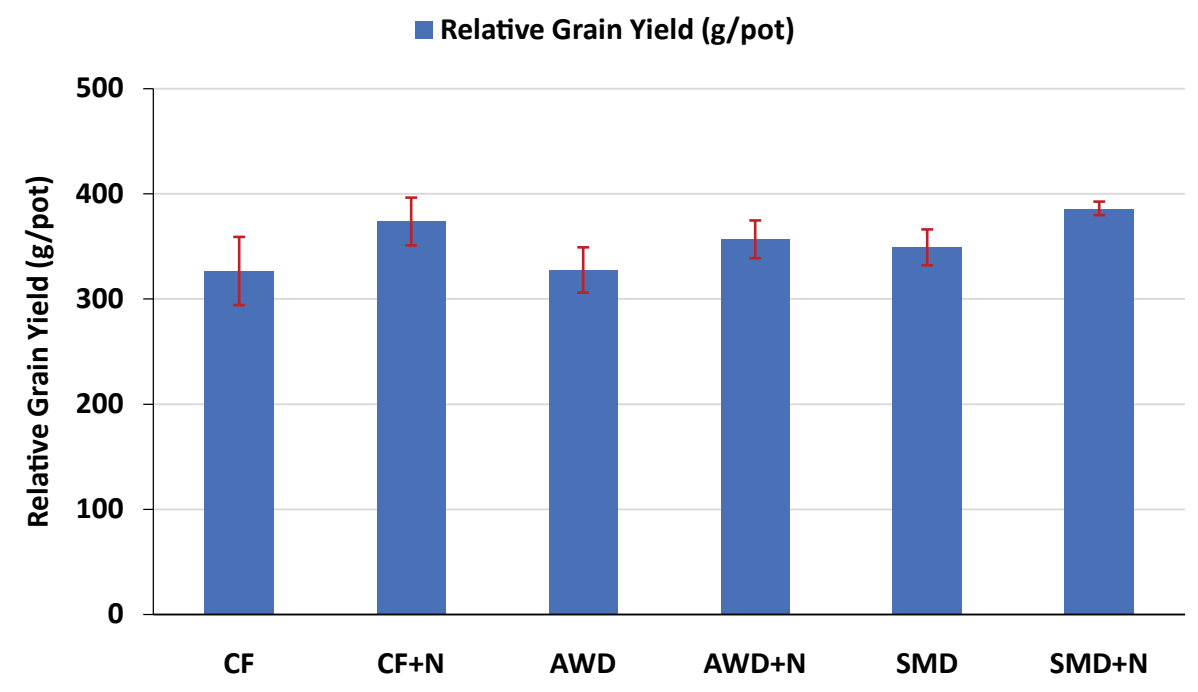

Figure 1: Effects of continuous flooding (CF), continuous flooding + nitrogen ( $C F+N)$, alternate wetting and drying (AWD), alternate wetting and drying + nitrogen $(A W D+N)$, single mid-season drying $(S M D)$ and single mid-season drying + nitrogen $(S M D+N)$ on rice yield. 
In previous studies reduction in grain yield is reported under severe soil drying conditions imposed during AWD [23,24]. The reduction in yield also depends on the growth stages when drying occurs, how much soil was dried, groundwater table, and soil hydrological conditions $[4,9]$.

\section{Leaf tissue}

No significant effect of irrigation and $\mathrm{N}$ application was observed in leaf tissue concentration in terms of leaf TP and TK (Figure 2). The addition of $\mathrm{N}$ to different irrigation management had no significant effect on leaf tissue concentration. In agreement to our result, no significant water by $\mathrm{N}$ interaction on $\mathrm{N}$ uptake was reported by Cabango et al. [45]. Potassium and K uptake was not affected by water treatment Cabango et al. (2004). In contrast, (Hamoud et al., 2019), reported higher $K$ concentrations in rice plant grown under CF than AWD [46]. The high K concentration may be due to presence of high amount of plant available $K$ under $C F$ than under AWD. Additionally, CF increase the availability of NPK, whereas water stress reduced their availability. Irrigation management under AWD may increase the concentration of some micronutrients while the concentration of other micronutrients may decrease in plants [25]. Norton, et al. [8] reported that AWD significantly decreased sodium ( $\mathrm{Na})$, magnesium ( $\mathrm{Mg}$ ), calcium (Ca), iron (Fe), arsenic ( $\mathrm{As})$, and molybdenum (Mo) concentration within rice shoot, and significantly increased manganese $(\mathrm{Mn})$, copper $(\mathrm{Cu})$, and zinc $(\mathrm{Zn})$ concentration in rice shoot. Alternate wet and dry treatment also had a significant effect on grain elements compared to CF. The concentration of sulfur (S), Ca, Fe, and As were significantly lower whereas the concentration of $\mathrm{Mn}, \mathrm{Cu}$, and cadmium (Cd) was significantly higher in AWD plots compared to $C F$ in both years [8]. However, the concentration of $\mathrm{Na}, \mathrm{Mg}$, and $\mathrm{K}$, were significantly different between treatments in single years. Phosphorus and $\mathrm{Zn}$ were the only elements that were not affected by AWD compared to $\mathrm{CF}$ [8]. In contrast, some studies reported an increase in $\mathrm{Zn}$ concentration in rice grain under AWD compared to CF $[26,27]$. It was observed that under AWD the straw $\mathrm{N}$ concentration was reduced significantly [28]. The low accumulation of $N$ in plants under AWD is associated with more loss of $\mathrm{N}$ due to denitrification and volatilization [29].

Although the determination of As was out of the scope of this study, previous research has shown rice grown under AWD had significantly decreased shoot and grain As compared to CF. Ten-fold increase in As concentration in rice grain was reported to rice grown under CF compared to non-flooded conditions [30,31].

\section{Soil quality}

Soil $\mathrm{pH}$ reduced significantly after rice cultivation irrespective of irrigation management and $\mathrm{N}$ treatment (Figure 3). Treatments had no significant effect on organic matter and TKN. However, M3P and M3K concentrations had increased significantly in the soils after rice cultivation irrespective of treatment, probably due to the inputs of $P$ and $\mathrm{K}$ from canal water that was used in the study. Our results are in agreement with Norton, et al. [8]. No significant difference in soil element concentration was observed between AWD and CF. Research studies indicated more $\mathrm{N}$ loss in the form of

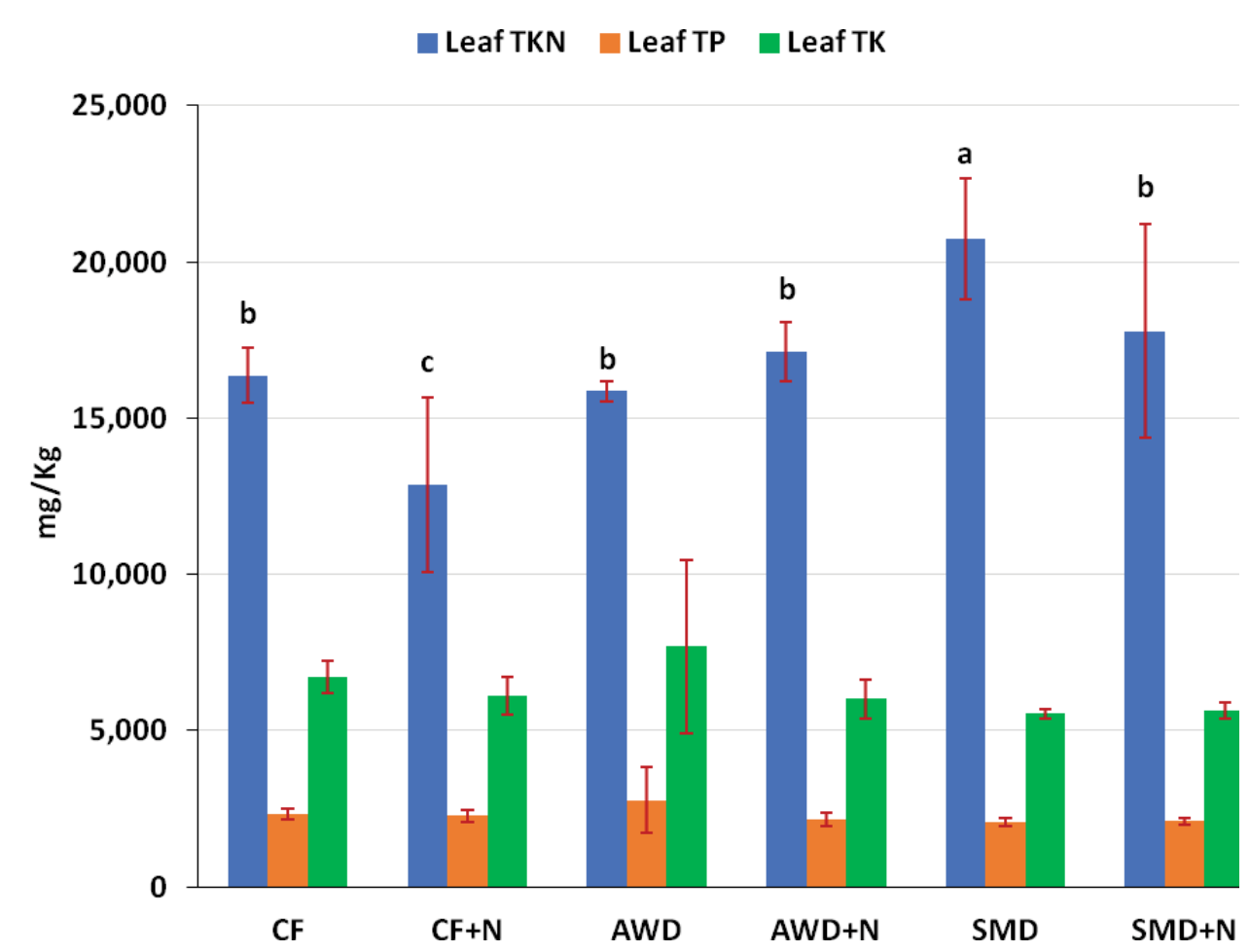

Figure 2: Effects of continuous flooding (CF), continuous flooding + nitrogen (CF $+N)$, alternate wetting and drying (AWD), alternate wetting and drying + nitrogen (AWD $+\mathrm{N})$, single mid-season drying (SMD) and single mid-season drying + nitrogen (SMD $+\mathrm{N})$ on total Kjeldahl nitrogen (TKN), total phosphorus (TP) and total potassium (TK) concentration of leaf tissue. 
a

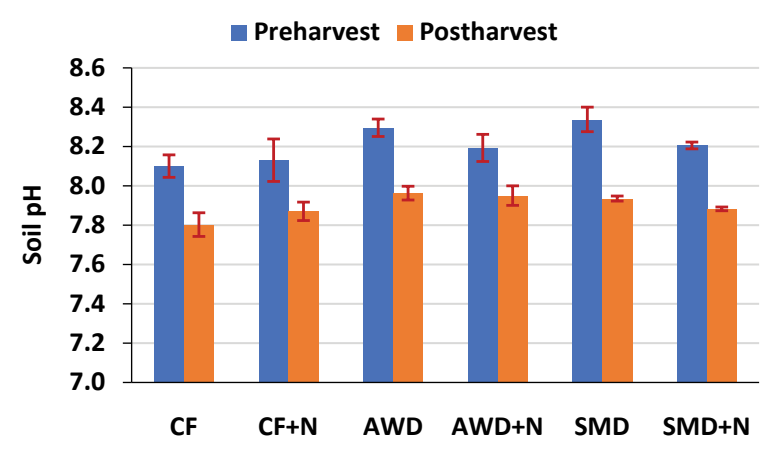

c

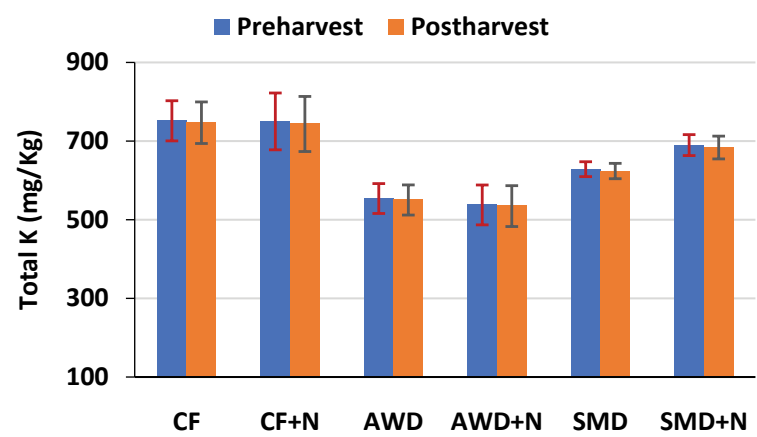

e

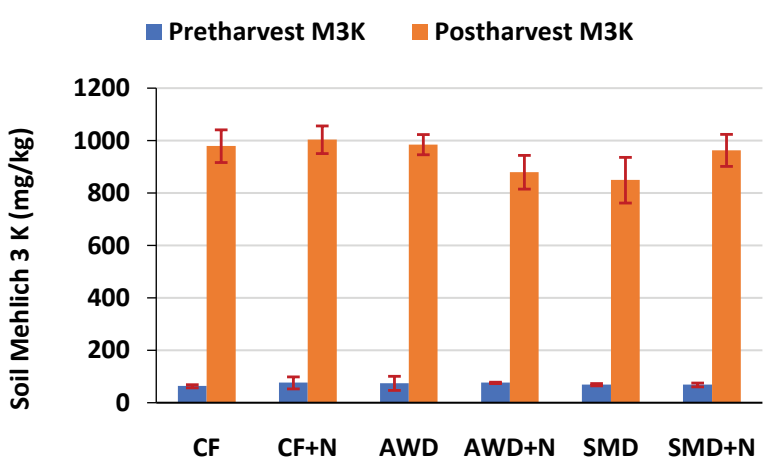

b

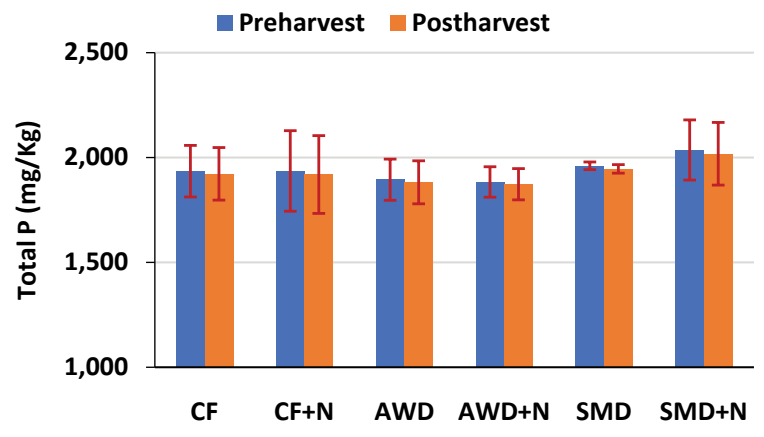

d

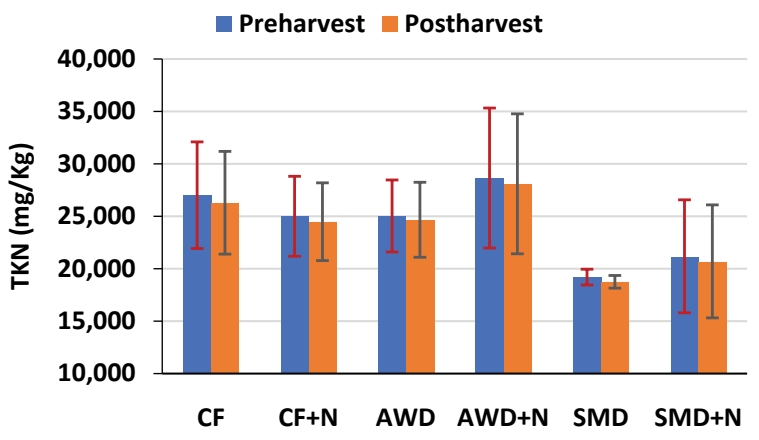

$\mathrm{f}$

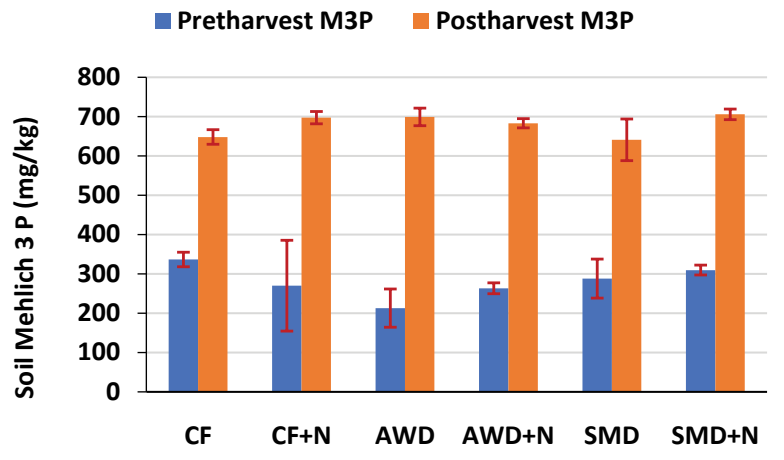

Figure 3: Effects of continuous flooding (CF), continuous flooding + nitrogen $(C F+N)$, alternate wetting and drying (AWD), alternate wetting and drying + nitrogen (AWD $+\mathrm{N})$, single mid-season drying (SMD) and single mid-season drying + nitrogen (SMD +N) on a) soil $\mathrm{pH}, \mathrm{b})$ total phosphorus, c) total potassium, d) total Kjeldahl nitrogen (TKN), e) Mehlich-3 P, f) Mehlich-3 K

nitrification and denitrification under AWD compared to CF [32]. In contrast, Wang, et al. [33] reported that AWD practice did not boost the loss of $\mathrm{N}$. Previous research has indicated synergistic interaction between $\mathrm{N}$ fertilizer and soil moisture [34]. Synergistic interaction can improve $\mathrm{N}$ use efficiency and crop yield if both $\mathrm{N}$ and water are managed timely [7,35]. The effect of AWD on N use efficiency (NUE) is not clear. Huda, et al. [36] reported AWD did not affect NUE. Lower NUE under AWD associated with more $\mathrm{N}$ losses which ultimately reduce the plant $\mathrm{N}$ uptake [37]. However, the $\mathrm{N}$ loss under AWD depends on the extent of soil drying $[33,38]$. Nitrogen application before re-wetting in AWD increased NUE due to synergetic interaction between $\mathrm{N}$ and water. In alkaline soil more $\mathrm{N}$ is lost via ammonia volatilization [39].

The availability of $P$ increased under CF as the supplementary release of $\mathrm{P}$ occurs under anaerobic conditions
[40]. Under AWD the availability of P decreased in the drying events which results in a reduction of $P$ in rice plants compared to CF [8]. To increase the $\mathrm{N}$ and $\mathrm{P}$ uptake under AWD or SMD drying events are recommended at $60 \%$ canopy coverage so that the applied $\mathrm{N}$ and $\mathrm{P}$ fertilizers are taken up by plants and $\mathrm{N}$ losses are minimized through coupled nitrification [41].

\section{Water quality}

Treatment did not affect water $\mathrm{pH}, \mathrm{TP}$, and TK. Water TKN has decreased over time irrespective of treatment (Figure 4). Decrease in TKN concentration over time might be associated with plant uptake or $\mathrm{N}$ losses due to leaching, volatilization losses of $\mathrm{N}$, or denitrification. Split application of $\mathrm{N}$ is common to increase NUE without potential leaching and run-off losses [42]. A single application of $\mathrm{N}$ at planting uses large amounts of fertilizer in early growth stages and too little at later stages. Canal water concentration was variable throughout the study, 
a

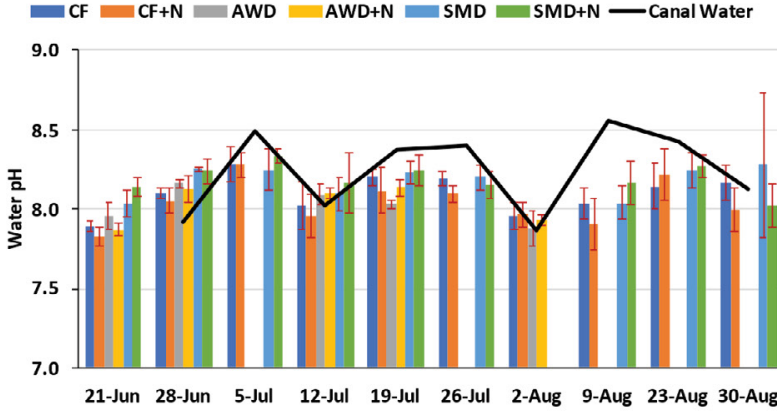

C

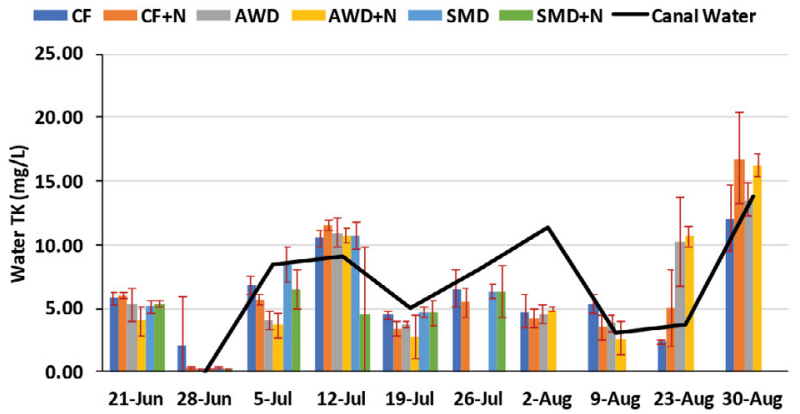

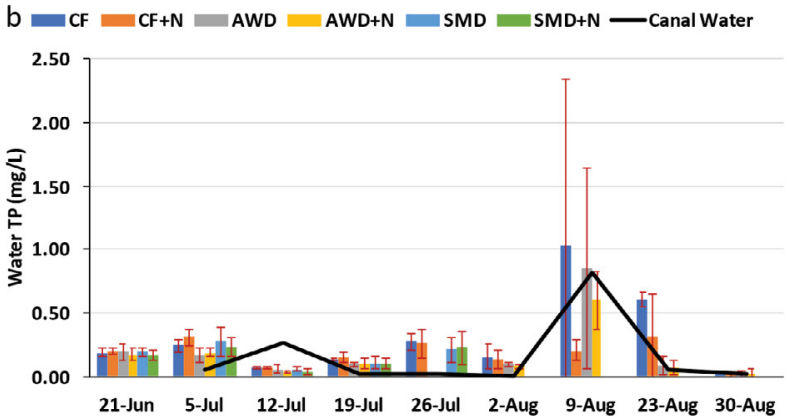

$\mathrm{d}=\mathrm{CF}=\mathrm{CF}+\mathrm{N}=\mathrm{AWD}=\mathrm{AWD}+\mathrm{N}=\mathrm{SMD}=\mathrm{SMD+N}-$ Canal Water

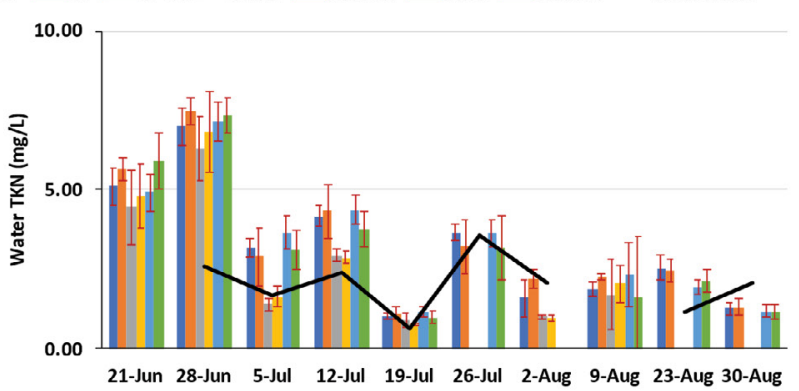

Figure 4: Effects of continuous flooding (CF), continuous flooding + nitrogen (CF $+N)$, alternate wetting and drying (AWD), alternate wetting and drying + nitrogen (AWD $+\mathrm{N})$, single mid-season drying (SMD) and single mid-season drying + nitrogen (SMD $+\mathrm{N})$ on water quality a) water $\mathrm{pH}, \mathrm{b}$ ) total phosphorus (TP), c) total potassium (TK), and d) total Kjeldahl nitrogen (TKN). Line graph shows canal water quality.

Note: No canal water data available for TKN on 9 and 23 August.

which may be due to variability in water quality discharge from different farms. This might have affected the water quality of our experiment. Drying events at AWD and SMD expose soil surface and increase the aeration that promotes weed emergence [43] whereas the CF rice system suppresses most of the weeds. Early drying event in AWD irrigation increase the weed infestation whereas drying events of AWD at 50$60 \%$ canopy coverage does not promote weed infestation [4].

\section{Conclusion}

Neither of the treatments affected rice yield cultivated on Histosols. Since there is no difference in yield, AWD and SMD could be an option for rice production in water scarcity conditions. This alternative irrigation management may also help in weed control. Soil texture should be in consideration while deciding AWD and SMD. For example, percolation loss of water from clay soil is slow and required more to achieve the required moisture potential whereas the percolation rate of sandy loam soil is fast and requires less time to achieve the required moisture potential. Similarly frequent and light irrigation is recommended for coarse-texture soils while fine-textured soils require heavy irrigation at the extended interval. Future research should focus on alternative water management strategy with the split application of $\mathrm{N}$ as the split application of $\mathrm{N}$ is common way to increase NUE without potential leaching and run-off losses. In addition, weed infestation under different water management system should be considered as weed infestation might be higher in AWD and SMD compared to CF resulting in lower yield $[6,44]$.

\section{Acknowledgements}

The authors would like to thank Florida Rice Grower's Inc. for funding this study. We would also like to thank Dr. Raju Khatiwada and Leandra Gonzalez for assistance with sampling and analyses.

\section{References}

1. Tabbal DF, Bouman BAM, Bhuiyan SI, et al. (2002) On-farm strategies for reducing water input in irrigated rice; case studies in the Philippines. Agric Water Manag 56: 93-112.

2. Tuong TP, Bouman BAM (2003) Rice production in water-scarce environments. In: Water productivity in agriculture: Limits and opportunities for improvement. 1: 13-42.

3. Bhatt R, Kaur R, Ghosh A (2019) Strategies to practice climatesmart agriculture to improve the livelihoods under the rice-wheat cropping system in south asia. In: Sustainable management of soil and environment. Springer, Singapore, 29-71.

4. Ishfaq M, Farooq M, Zulfiqar U, et al. (2020) Alternate wetting and drying: A water-saving and ecofriendly rice production system. Agric Water Manag 241: 106363.

5. Lin X, Zhou W, Zhu D, et al. (2005) Effect of SWD irrigation on photosynthesis and grain yield of rice (Oryza sativa L). Field Crops Res 94: 67-75.

6. Umesh MR, Chittapur BM, Angadi S (2017) Alternate wetting and drying (AWD) irrigation for rice to enhance water productivity and sustainable production: A review. J Farm Sci 30: 441-449.

7. Djaman K, Mel VC, Diop L, et al. (2018) Effects of alternate wetting and drying irrigation regime and nitrogen fertilizer on yield and nitrogen use efficiency of irrigated rice in the Sahel. Water 10: 711. 
8. Norton GJ, Shafaei M, Travis AJ, et al. (2017) Impact of alternate wetting and drying on rice physiology, grain production, and grain quality. Field Crops Res 205: 1-13.

9. Carrijo DR, Lundy ME, Linquist BA (2017) Rice yields and water use under alternate wetting and drying irrigation: A metaanalysis. Field Crops Res 203: 173-180.

10. Liu X, Zhou T, Liu Y, et al. (2019) Effect of mid-season drainage on $\mathrm{CH}_{4}$ and $\mathrm{N}_{2} \mathrm{O}$ emission and grain yield in rice ecosystem: A metaanalysis. Agric Water Manag 213: 1028-1035.

11. Rahman SM, Kakuda KI, Sasaki Y, et al. (2013) Effect of midseason drainage (msd) on growth and yield of rice in north east japan. Amer J Plant Nutr Fertil Tech 3: 33-42.

12. Wassmann R, Jagadish SVK, Sumfleth K, et al. (2009) Regional vulnerability of climate change impacts on Asian rice production and scope for adaptation. Adv Agron 102: 91-133.

13. Oo NML, Shivay YS, Kumar D (2007) Effect of nitrogen and sulphur fertilization on yield attributes, productivity and nutrient uptake of aromatic rice (Oryza sativa). Indian J Agric Sci 77: 772-775.

14. Rice CW, Smith MS (1984) Short-term immobilization of fertilizer nitrogen at the surface of no-till and plowed soils. Soil Sci Soc Am J 48: 295-297.

15. Binti Said FN, Yusop MK, Oad FC (2014) Nutrient uptake, pH changes and yield of rice under slow release sulfur-coated urea fertilizers. Aust J Crop Sci 8: 1359-1366.

16. Atwill RL, Krutz L, Bond JA, et al. (2018) Water management strategies and their effects on rice grain yield and nitrogen use efficiency. J Soil Water Conserv 73: 257-264.

17. Mikkelsen DS (1987) Nitrogen budgets in flooded soils used for rice production. Plant Soil 71-97.

18. Bhadha JH, Khatiwada R, Tootoonchi M, et al. (2019) Interpreting redox potential (Eh) and diffusive fluxes of phosphorus $(P)$ and nitrate $\left(\mathrm{NO}_{3}{ }^{-}\right)$from commercial rice grown on histosols. Paddy Water Environ 18: 167-177.

19. Tootoonchi M, Bhadha JH, Lang TA, et al. (2018) Reducing drainage water phosphorus concentration with rice cultivation under different water management regimes. Agric Water Manag 205: 30-37.

20. Bhadha JH, Khatiwada R, Galindo S, et al. (2018) Evidence of soil health benefits of flooded rice compared to fallow practice. Sustain Agric Res 7: 31-41.

21. Howell KR, Shrestha P, Dodd IC (2015) Alternate wetting and drying irrigation maintained rice yields despite half the irrigation volume, but is currently unlikely to be adopted by smallholder lowland rice farmers in Nepal. Food Energy Secur 4: 144-157.

22. Yang J, Zhang J (2010) Crop management techniques to enhance harvest index in rice. J Exp Bot 61: 3177-3189.

23. Yang J, Huang D, Duan H, et al. (2009) Alternate wetting and moderate soil drying increases grain yield and reduces cadmium accumulation in rice grains. J Sci Food Agric 89: 1728-1736.

24. Sudhir-Yadav, E Humphreys, T Li, et al. (2012) Evaluation of tradeoffs in land and water productivity of dry seeded rice as affected by irrigation schedule. Field Crops Res 128: 180-190.

25. Price AH, Norton GJ, Salt DE, et al. (2013) Alternate wetting and drying irrigation for rice in Bangladesh: Is it sustainable and has plant breeding something to offer?. Food Energy Secur 2: 120129.
26. Wissuwa M, Ismail AM, Graham RD (2008) Rice grain zinc concentrations as affected by genotype, native soil-zinc availability, and zinc fertilization. Plant Soil 306: 37-48.

27. Wang YY, Wei YY, Dong LX, et al. (2014) Improved yield and Zn accumulation for rice grain by $\mathrm{Zn}$ fertilization and optimized water management. J Zhejiang Univ Sci B 15: 365-374.

28. Tan X, Shao D, Gu W, et al. (2015) Field analysis of water and nitrogen fate in lowland paddy fields under different water managements using HYDRUS-1D. Agric Water Manag 150: 6780 .

29. Tan X, Shao D, Liu H, et al. (2013) Effects of alternate wetting and drying irrigation on percolation and nitrogen leaching in paddy fields. Paddy Water Environ 11: 381-395.

30. Xu XY, McGrath SP, Meharg AA, et al. (2008) Growing rice aerobically markedly decreases arsenic accumulation. Environ Sci Technol 42: 5574-5579.

31. Norton GJ, Adomako EE, Deacon CM, et al. (2013) Effect of organic matter amendment, arsenic amendment and water management regime on rice grain arsenic species. Environ Pollut 177: 38-47.

32. Ju XT, Xing GX, Chen XP, et al. (2009) Reducing environmental risk by improving $\mathrm{N}$ management in intensive Chinese agricultural systems. Proc Natl Acad Sci 106: 3041-3046.

33. Wang $X$, Suo $Y$, Feng Y, et al. (2011) Recovery of $15 \mathrm{~N}$-labeled urea and soil nitrogen dynamics as affected by irrigation management and nitrogen application rate in a double rice cropping system. Plant Soil 343: 195-208.

34. Wang Y, Zhang X, Liu X, et al. (2013) The effects of nitrogen supply and water regime on instantaneous WUE, time-integrated WUE and carbon isotope discrimination in winter wheat. Field Crops Res 144: 236-244.

35. Yang J (2015) Approaches to achieve high grain yield and high resource use efficiency in rice. Front Agric Sci Eng 2: 115-123.

36. Huda A, Gaihre YK, Islam MR, et al. (2016) Floodwater ammonium, nitrogen use efficiency and rice yields with fertilizer deep placement and alternate wetting and drying under triple rice cropping systems. Nutr Cycl Agroecosystems 104: 53-66.

37. Zou J, Huang $Y$, Zheng $X$, et al. (2007) Quantifying direct $\mathrm{N}_{2} \mathrm{O}$ emissions in paddy fields during rice growing season in mainland China: Dependence on water regime. Atmos Environ 41: 80308042.

38. Chu G, Wang Z, Zhang H, et al. (2016) Agronomic and physiological performance of rice under integrative crop management. Agron J 108: 117-128.

39. Moormann FR, Van Breemen N (1978) Rice: Soil, water, land. Int Rice Res Inst. Philippines.

40. Young EO, Ross DS (2001) Phosphate release from seasonally flooded soils: A laboratory microcosm study. J Environ Qual 30: 91-101.

41. LaHue GT, Chaney RL, Adviento-Borbe MA, et al. (2016) Alternate wetting and drying in high yielding direct-seeded rice systems accomplishes multiple environmental and agronomic objectives. Agric Ecosyst Environ 229: 30-39.

42. Randall GW, Schmitt MA (1998) Advisability of fall-applying nitrogen. In: Proceedings Wisconsin Fertilizer. Aglime and Pest Management Conference, 90-96.

43. Murugan G, Bhagavathi MS, Stalin P, et al. (2019) Effect of 
irrigation practices on weeds and its impact on yield in different rice establishing methods. J pharmacogn phytochem 8: 21992201.

44. Jabran K, Ullah E, Hussain M, et al. (2015) Water saving, water productivity and yield outputs of fine-grain rice cultivars under conventional and water-saving rice production systems. Exp Agric 51: 567-581.
45. Cabangon RJ, Tuong TP, Castillo EG, Bao LX, Lu G, et al. (2004) Effect of irrigation method and $\mathrm{N}$-fertilizer management on rice yield, water productivity and nutrient-use efficiencies in typical lowland rice conditions in China. Paddy Water Environ 2: 195206.

46. Hamoud YA, Wang Z, Guo X, Shaghaleh $H$, Sheteiwy $M$, et al. (2019) Effect of irrigation regimes and soil texture on the potassium utilization efficiency of rice. Agronomy 9: 100. 